\title{
Moustached Pseudodiamesa is still in waiting for a modern cytogenetic approach and a taxonomic revision: a reply to Willassen
}

\author{
Boris P. Ilyashuk ${ }^{1} \&$ Elena A. Ilyashuk ${ }^{1,2}$ \\ ${ }^{1}$ Institute of North Industrial Ecology Problems, Kola Science Centre, Russian Academy of Sciences, 14 \\ Fersman St., Apatity, Murmansk reg.184209, Russia.E-mail:ilboris@yandex.com \\ ${ }^{2}$ Institute of Ecology, University of Innsbruck, Technikerstraße 25, 6020 Innsbruck, Austria. \\ E-mail: elena.ilyashuk@uibk.ac.at
}

Beginning with the study of chironomid subfossils in Schwarzsee ob Sölden, the Austrian Alps (Ilyashuk et al. 2011), we have tried to compile all available information about aquatic invertebrates in this high-alpine lake. To our surprise, we found rather contradictory data on the Pseudodiamesa species. Janecek (1998) reported that $P$. nivosa inhabits the lake whereas Raddum et al. (2004) have found that the Pseudodiamesa subfossils from a short core taken in the lake are represented by P. branickii. To all appearances, difficulties in the identification of Pseudodiamesa subfossils resulted in the mentioned taxonomic inconsistency. The following study of contemporary Pseudodiamesa larvae and their subfossils showed that the genus is represented by $P$. nivosa in this lake (Ilyashuk et al. 2011). However, we encountered a number of contradictions in the available literature for identification of contemporary Pseudodiamesa larvae. Some of them are noted in Willassen (2011). In Ilyashuk et al. (2010), we summarise current experience in splitting the genus into two intra-genus morphotypes within the subfossil material from different Arctic and Alpine regions. Later, working with subfossils from another high-alpine lake, we got chironomid remains of much better preservation and found that the P. nivosa subfossils have the labral lamellae and the pecten epipharyngis consisting of seven scales (Fig. 1), as is described in Schmid (1993). The observations by Willassen (2011) based on contemporary material confirm it as well. Nevertheless, we would like to emphasize that the mentum is a well-preserved structure in subfossil specimens and can be one of the best morphological characters for differentiating Pseudodiamesa species-group morphotypes in subfossil material (Ilyashuk et al. 2010).

The current state of knowledge on the genus Pseudodiamesa does not allow us to confirm or disprove hypotheses concerning synonymisation of some species. Schnell and Willassen (1991) suppose that $P$. nivosa is synonymous with $P$. arctica and Makarchenko (1998) assumes that $P$. nepalensis is a synonym of P. nivosa. Both hypotheses are realistic and testable, taking into account modern cytogenetic approaches and techniques. Unfortunately, the discussion in Willassen (2011) does not add new data to check the hypothesis about synonymisation of $P$. nivosa and $P$. arctica. However, there are the first successful steps in resolving some Pseudodiamesa taxonomic problems. A recent comparative study of karyotypes of some 

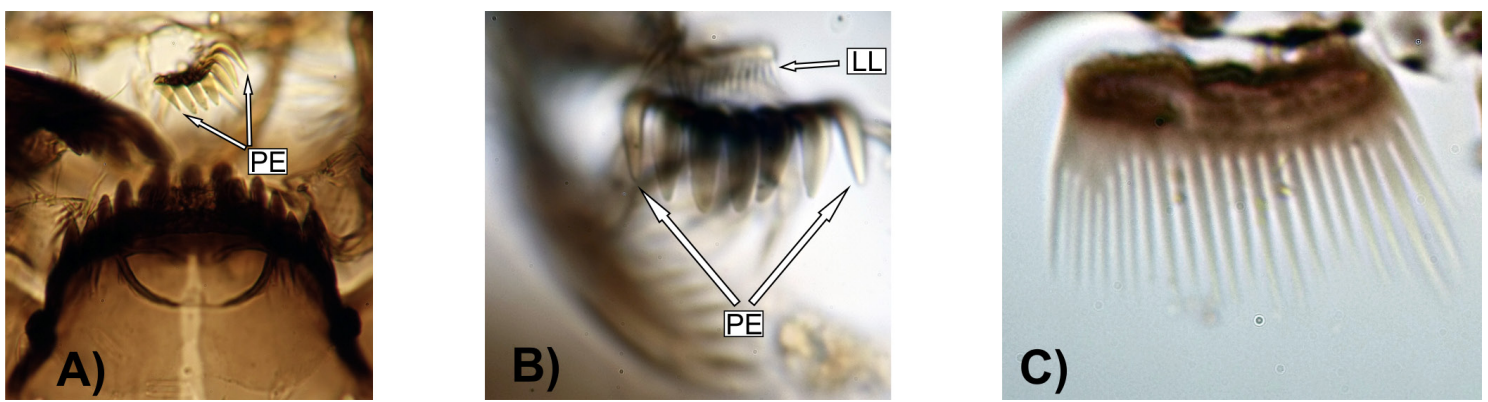

Figure 1. Pseudodiamesa nivosa (Goetghebuer) subfossils from a high-mountain lake in the Italian Alps: A) pecten epipharyngis (PE); B) pecten epipharyngis (PE) and labral lamella (LL); C) labral lamella.

Pseudodiamesa species, conducted by Ermolaeva (2005) and supervisored by Dr. E. Makarchenko and Dr. I. Kiknadze, provides evidence that P. nivosa, P. stackelbergi, and P. latistyla are valid species. Moreover, comparative karyological analysis of $P$. branickii, collected from different regions in Eurasia (Germany, Bulgaria, Kyrgyzstan, Russian Far East, and Japan) revealed that there are at least four distinct chromosomal races, which may represent sibling species corresponding to the P. branickii morphotype (Ermolaeva 2005). Hopefully, other species of this genus will be included in subsequent comparative karyological analyses.

\section{References}

Ermolaeva, O.V. 2005. Citotaksonomicheskiy analiz vidov podsemeystv Diamesinae i Prodiamesinae: (Diptera, Chironomidae) [Cytotaxonomic analysis of species of the subfamilies Diamesinae and Prodiamesinae (Diptera, Chironomidae)]. Ph.D. Thesis, Novosibirsk State University, Novosibirsk, Russia. $239 \mathrm{p}$.

Ilyashuk, B.P., Ilyashuk, E.A., Makarchenko, E.A. and Heiri, O. 2010. Midges of the genus Pseudodiamesa Goetghebuer (Diptera, Chironomidae): current knowledge and palaeoecological perspective. - Journal of Paleolimnology 44: 667-676.

Ilyashuk, E.A., Koinig, K.A., Heiri, O., Ilyashuk B.P. and Psenner, R. 2011. Holocene temperature variations at a high-altitude site in the Eastern Alps: a chironomid record from Schwarzsee ob Sölden, Austria. Quaternary Science Reviews 30: 176-191.

Janecek, B. 1998. Fauna Aquatica Austriaca, Taxonomie und Ökologie aquatischer wirbelloser Organismen, Teil V. Diptera: Chironomidae (Zuckmücken), Larvenstadien mitteleuropäischer Gattungen und österreichischer Arten, Bestimmung von 4. Universität für Bodenkultur, Abteilung Hydrobiology, Wien, Austria. 117 p.

Makarchenko, E.A. 1998. Chironomidy podsemeystva Diamesinae (Diptera, Chironomidae) severnogo polushariya: sistematika, biologiya, biogeografiya [Chironomids of the subfamily Diamesinae (Diptera, Chironomidae) of the Northern Hemisphere: systematics, biology, and biogeography]. Dr.Sci.Thesis, FEB of Russian Academy of Sciences, Vladivostok, Russia. 518 p.

Raddum, G., Erikson, L., Fott, J., Halvorsen, G.A., Heegaard, E., Kohout, L., Kifinger, B., Schaumberg, J., Maetze, A. and Zahn, H. 2004. Recovery from acidification of invertebrate fauna at ICP Water sites in Europe and North America. ICP Waters report 75/2004, Norwegian Institute for Water Research, Oslo, Norway.

Schmid, P.E. 1993. A key to the larval Chironomidae and their instars from Austrian Danube Region streams and rivers. Part I, Diamesinae, Prodiamesinae and Orthocladiinae. Federal Institute for Water Quality of the Ministry of Agriculture and Forestry, Wien.

Schnell, Ø.A. and Willassen, E. 1991. Fjærmyggarten Pseudodiamesa arctica (Malloch) i to høyfjellsreservoarer (The chironomid species Pseudodiamesa arctica (Malloch) in two high mountain reservoirs). Report No 76, Freshwater Ecology and Inland Fisheries Laboratory, Department of Zoology, University of Bergen, Bergen, Norway.

Willassen, E. 2011. Pseudodiamesa nivosa or arctica? A confounded story of a midge moustache and an attempt at some taxonomic orthodontics. - Chironomus Newsletter on Chironomidae Research 24: XX. 